\title{
UJI AKTIVITAS ANTIBAKTERI ASAM LEMAK HASIL HIDROLISIS MINYAK MIKROALGA Chlorella sp.
}

\author{
Diah Kumalasari, A. Ghanaim Fasya, Tri Kustono Adi, Anik Maunatin \\ Jurusan Kimia Fakultas Sains dan Teknologi Universitas Islam Negeri Maulana Malik Ibrahim Malang
}

\begin{abstract}
The Chlorella sp. is a microscopic unicellular microalgae that contains organic oils which can be hydrolyzed into fatty acids. Fatty acids is one of the active components in microalgae which allegedly acted as an antibacterial. The aim of this study is to determine the antibacterial activity of fatty acids from the hydrolysis process of microalgae Chlorella sp. oil against Escherichia coli and Staphylococcus aureus.

Insulating oil Chlorella sp. performed by the Soxhlet method with n-hexane. Chlorella sp. oil was hydrolyzed with $12 \% \mathrm{KOH}$ in methanol to obtain fatty acids. The antibacterial activity of these fatty acids was tested against $E$. coli and $S$. aureus using the disc diffusion method.

The result showed that the yield of oil Soxhlet Chlorella sp. was equal to $6.28 \%$. Hydrolysis of Chlorella $s p$. oil produced a yield of $69.57 \%$. Fatty acids have antibacterial activity against $S$. aureus bacteria, but not against the bacteria $E$. coli. Fatty acids inhibition zone from Chlorella $s p$. against the bacteria $S$. aureus at the concentration $0.5 ; 1 ; 1.5 ; 2$; and $2.5 \%$ respectively are $1.8 ; 1.9 ; 3.2 ; 3.5$; and $3 \mathrm{~mm}$.
\end{abstract}

Keywords: Microalgae Chlorella sp., Fatty acids, Soxhlet extraction, antibacterial activity.

\section{ABSTRAK}

Chlorella sp. merupakan mikroalga uniselular berukuran mikroskopis yang banyak mengandung minyak organik yang dapat dihidrolisis menjadi asam lemak. Asam lemak merupakan salah satu komponen aktif dalam mikroalga yang diduga berperan sebagai antibakteri. Penelitian ini bertujuan untuk mengetahui aktivitas antibakteri asam lemak hasil hidrolisis minyak mikroalga Chlorella sp. terhadap bakteri Escherichia coli dan Staphylococcus aureus.

Isolasi minyak Chlorella sp. dilakukan dengan metode Soxhletasi dengan pelarut n-heksana. Minyak Chlorella sp. dihidrolisis dengan $\mathrm{KOH} 12 \%$ dalam pelarut metanol untuk mendapatkan asam lemak. Asam lemak yang dihasilkan diuji aktivitas antibakteri terhadap bakteri E. coli dan S. aureus menggunakan metode difusi cakram.

Hasil penelitian menunjukkan bahwa rendemen Soxhletasi minyak Chlorella sp. adalah sebesar 6,28\%. Hidrolisis minyak Chlorella sp. menghasilkan rendemen sebesar 69,57 \%. Asam lemak memiliki aktivitas antibakteri terhadap bakteri $S$. aureus, tetapi tidak terhadap bakteri E. coli. Zona hambat asam lemak Chlorella $s p$. terhadap bakteri $S$. aureus pada konsentrasi 0,$5 ; 1 ; 1,5 ; 2$; dan $2,5 \%$ secara berturut-turut adalah 1,$8 ; 1,9 ; 3,2$; 3,5 ; dan $3 \mathrm{~mm}$.

Kata Kunci: Mikroalga Chlorella sp., asam lemak, ekstraksi Soxhlet, aktivitas antibakteri.

\section{PENDAHULUAN}

Allah SWT berfirman dalam al Qur'an surat asy Syu'ara ayat 7:

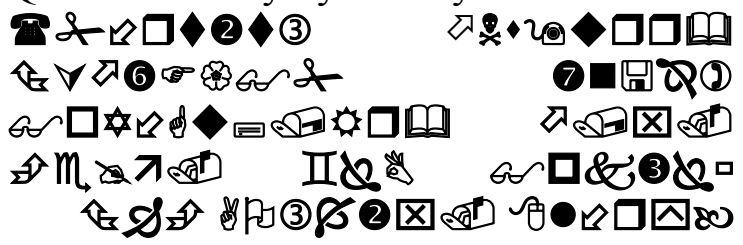

\section{"dan Apakah mereka tidak memperhatikan} bumi, berapakah banyaknya Kami tumbuhkan di bumi itu pelbagai macam tumbuh-tumbuhan yang baik?". (Qs. asy Syu'ara: 7).

QS. asy Syu'ara ayat 7 tersebut menyeru kepada manusia agar memperhatikan seluruh isi bumi ciptaan Allah, yang di dalamnya terdapat tumbuhtumbuhan yang baik dengan berbagai jenis, bentuk, dan warna. Ayat tersebut juga memerintahkan kepada manusia agar mau mencari dan berpikir tentang manfaat 
tumbuhan yang telah disediakan oleh Allah SWT yang ada di dalamnya berupa rahasia dan keajaiban, agar diambil manfaatnya dalam kehidupan misalnya sebagai obatobatan.

Jenis tanaman yang bermanfaat dalam bidang kesehatan tidak hanya berasal dari tanaman tingkat tinggi, tanaman tingkat rendah yang berukuran mikroskopispun mampu menghasilkan senyawa-senyawa yang bermanfaat, salah satunya yakni mikroalga. Mikroalga merupakan mikroorganisme fotosintetik dengan morfologi sel yang bervariasi, baik uniseluler maupun multiseluler. Mikroalga merupakan produsen alami dari ekosistem perairan yang dapat menghasilkan energi sehingga keberadaannya sebagai organisme hidup yang berukuran mikroskopis sudah mulai banyak diteliti (Damianus, 2011).

Pemanfaatan mikroalga terutama di bidang kesehatan adalah potensinya sebagai antibakteri. Kellam dan Walker (1989) menyebutkan bahwa ekstrak metanol dan heksana dari 132 jenis mikroalga laut mempunyai aktivitas antibakteri terhadap 6 bakteri uji. Salah satunya adalah mikroalga Chlorella sp.. Chlorella sp. merupakan mikroalga uniselular berukuran mikroskopis yang tergolong dalam kelompok Chlorophyta (Steenblock, 1996).

Chlorella sp. dalam tubuhnya banyak mengandung lipid atau minyak organik sebesar 28 - $32 \%$ (Chisti, 2007). Hal tersebut juga didukung dengan penelitian Saadudin, dkk. (2011) yang menyebutkan bahwa Chlorella sp. mempunyai kandungan lipid yang tertinggi dibandingkan dengan spesies lainnya yaitu Nannochloropsis sp., Spirulina sp., Dunaliela sp., Tetraselmis sp.. Kandungan minyak nabati yang tinggi mengindikasikan tingginya kandungan asam lemak (Rachmaniah, dkk., 2010).

Berdasarkan data tersebut, peneliti ingin memanfaatkan kelimpahan minyak
Chlorella sp. sebagai suatu senyawa antibakteri dengan terlebih dahulu dihidrolisis menjadi asam lemak, dikarenakan asam lemak merupakan salah satu komponen aktif dalam mikroalga yang diduga berperan sebagai antibakteri. Hasil Kromatografi Gas Spektrometri Massa (KG-SM) ekstrak etanol Dunaliella salina sebagai antibakteri dari penelitian Agustini dan Kusmiyati (2010) diperoleh senyawasenyawa golongan asam lemak. Asamasam lemak tersebut antara lain asam heksadekanoat (asam palmitat), asam heksadekanoat, asam 8,11-oktadekadieoat, asam 9,12-oktadekadienoat (asam linoleat). Kusmiyati dan Agustini (2007) dalam penelitiannya juga menghasilkan kesimpulan bahwa hasil identifikasi senyawa antibakteri dari mikroalga Porphyridium cruentum pada fase awal stasioner dengan KG-SM menunjukkan senyawa dominan yaitu asam lemak heksadekanoat (asam palmitat).

Berbagai metode telah diujicobakan agar minyak dan lemak dalam Chlorella sp. dapat terekstrak dalam jumlah maksimal. Berdasarkan penelitian Rachmaniah dkk. (2010) diperoleh hasil bahwa metode yang efektif untuk mengekstraksi minyak mikroalga Chlorella sp. kondisi kering adalah metode Soxhletasi dengan pelarut n-heksana.

Minyak dapat dihidrolisis menjadi asam lemak dengan menggunakan katalis asam, basa, maupun secara enzimatis. Beberapa peneliti memilih katalis basa untuk menghidrolisis minyak nabati karena reaksi hidrolisis berlangsung secara irreversible. Fasya (2011) melakukan penelitian untuk menghidrolisis minyak biji selasih

Penelitian tersebut menggunakan katalis $\mathrm{KOH} 12 \%$ dalam metanol dan menghasilkan campuran asam-asam lemak dengan rendemen sebanyak 77,90\%.

Asam lemak yang dihasilkan diharapkan mampu menekan pertumbuhan bakteri patogen yang keberadaannya 
merugikan manusia. Bakteri yang sering menginfeksi manusia diantaranya bakteri Escherichia coli (E. coli) dan Staphylococcus aureus (S. aureus). Gejala penyakit yang disebabkan oleh $E$. coli pada sebagian kasus berupa kram dan diare (Nuriyani, 2011). Gejala penyakit lainnya adalah saluran kemih, pneumonia, bakterernia, meningitis neonatal, dan cholangitis (Putri, 2013). Sedangkan penyakit infeksi yang disebabkan oleh $S$. aureus adalah bisul, jerawat, impetigo, dan infeksi luka. S. aureus juga merupakan penyebab utama infeksi nosokomial, keracunan makanan, dan sindroma syok toksik (Ryan, dkk., 1994).

Perbanyakan biomassa Chlorella $s p$. dapat dilakukan menggunakan teknik kultur. Kultur mikroalga membutuhkan faktor pendukung hidup agar diperoleh biomassa dalam jumlah maksimal sehingga diharapkan kandungan minyak atau lemak dalam mikroalga juga maksimal. Salah satu media alami yang dapat digunakan untuk pertumbuhan mikroalga Chlorella $s p$. adalah Medium Ekstrak Tauge (MET). Hasil penelitian Prihantini dkk. (2005) memperlihatkan bahwa Chlorella sp. yang dikultivasi dalam Medium Ekstrak Tauge (MET) konsentrasi $4 \%$ dapat menghasilkan kerapatan sel yang cukup tinggi.

\section{METODOLOGI PENELITIAN}

Penelitian ini dilaksanakan pada bulan Maret - Juli 2014 di Laboraturium Kimia Organik, Laboratorium Bioteknologi Jurusan Kimia dan Laboratorium Ekologi Jurusan Biologi Fakultas Sains dan Teknologi Universitas Islam Negeri (UIN) Maulana Malik Ibrahim Malang.

\section{Alat dan Bahan}

Alat-alat yang digunakan dalam penelitian ini diantaranya adalah labu kultur $1000 \mathrm{~mL}$, lampu TL 36 Watt, timer, kuvet, hot plate, sentrifuse, neraca analitik, seperangkat alat gelas, rotary evaporator vacumm, termometer, penangas air dan minyak, seperangkat ekstraktor Soxhlet, seperangkat alat refluks, desikator, pendingin (freezer), oven, lemari asam, magnetic stirrer, tabung gas $\mathrm{N}_{2}$, Instrumen Kromatografi Gas-Spektrometer Massa (KG-SM), laminar air flow, pengaduk, gelas arloji, cawan petri, tabung reaksi, kertas whatman no. 42, jarum ose, inkubator, alumunium foil, tissue, kertas saring, kapas, pinset, autoklaf, bunsen burner, pipet mikro, dan penggaris. Semua peralatan gelas untuk proses kultivasi disterilisasi menggunakan air panas.

Bahan utama yang digunakan dalam penelitian ini yaitu isolat mikroalga Chlorella sp. yang diperoleh dari Laboratorium Ekologi. Bahan yang digunakan untuk kultivasi Chlorella $s p$. adalah tauge kacang hijau dan aquades. Bahan-bahan kimia yang digunakan untuk ekstrak minyak Chlorella sp. adalah nheksana. Sedangkan untuk hidrolisis minyak Chlorella sp. adalah $\mathrm{KOH} 12 \%$, metanol, $\mathrm{H}_{2} \mathrm{SO}_{4} 1 \mathrm{M}$, aquades dan $\mathrm{n}$ heksana.

Bahan-bahan yang digunakan untuk uji aktivitas antibakteri diantaranya adalah aquades, biakan murni Escherichia coli dan Staphylococcus aureus, spirtus, media Nutrient Agar (NA), media Nutrient Broth (NB), penisilin dan streptomisin.

\section{Pembuatan Medium Ekstrak Tauge}

Pembuatan medium ekstrak tauge diawali dengan pembuatan larutan stok MET (b/v) yaitu 100 gram tauge direbus dalam $500 \mathrm{~mL}$ aquades yang mendidih sampai volume larutan menjadi setengahnya. Medium ekstrak tauge dibuat dengan cara melarutkan ekstrak tauge ke dalam aquades dengan konsentrasi $4 \%$ (v/v) yakni $24 \mathrm{~mL}$ ekstrak tauge dalam 576 $\mathrm{mL}$ aquades (Prihantini, dkk., 2005).

\section{Kultivasi Chlorella sp. dalam MET}


Sebanyak $100 \mathrm{~mL}$ kultur Chlorella $s p$. diinokulasikan ke dalam $600 \mathrm{~mL}$ medium ekstrak tauge. Labu kultur diletakkan ke dalam rak kultur dengan pencahayaan 2 buah lampu TL 36 Watt (intensitas cahaya 1000 - 4000 lux) dan foto periodisitas 14 jam terang dan 10 jam gelap (Prihantini, dkk., 2005).

\section{Perhitungan Jumlah Sel Chlorella sp.}

Mikroalga Chlorella sp. yang telah dikultivasi diambil menggunakan mikropipet dan diteteskan pada alat Haemacytometer. Jumlah sel Chlorella sp. yang ada dalam kotak hitung Haemacytometer dihitung kemudian jumlah sel yang diperoleh selanjutnya dihitung berdasarkan rumus sebagai berikut (Eaton, dkk., 2005 dalam Merizawati, 2008):

$$
N=n x \frac{16}{\sum_{i=1}^{16} K b i} \times \frac{1}{10^{-4}}
$$

Keterangan :

$$
\begin{aligned}
& \mathrm{N}=\text { Kelimpahan individu (sel/mL) } \\
& \mathrm{n} \quad=\text { Jumlah sel } \\
& 16=\text { Jumlah kotak kecil } \\
& \sum_{i=1}^{16} K b i=\text { Jumlah kotak kecil yang } \\
& 10^{-4} \text { diamati pada Haemacytometer } \\
& 10^{-4}=\text { Volume air sampel yang }
\end{aligned}
$$

\section{Pemanenan Chlorella sp.}

Mikroalga Chlorella sp. yang telah dikultivasi dan mencapai fase awal stasioner (hari ke-8) dipanen dengan cara disentrifuse selama 15 menit dengan kecepatan 3000 rpm sehingga terpisah antara biomassa dengan filtrat. Bagian biomassa Chlorella sp. diambil untuk selanjutnya dianalisis kadar air dan diekstraksi secara Soxhletasi.

\section{Preparasi Sampel}

Biomassa Chlorella sp. ditempatkan pada cawan kemudian dikeringkan dengan oven pada suhu $30^{\circ} \mathrm{C}$ sampai diperoleh biomassa Chlorella sp. kering dengan kadar air kurang dari $10 \%$.

\section{Analisa Kadar Air}

Cawan porselen dipanaskan dalam oven pada suhu $100-105{ }^{\circ} \mathrm{C}$ selama \pm 15 menit untuk menghilangkan kadar airnya, kemudian cawan disimpan dalam desikator sekitar 10 menit. Cawan tersebut selanjutnya ditimbang dan dilakukan perlakuan yang sama sampai diperoleh berat cawan yang konstan. Serbuk mikroalga Chlorella sp. diambil 5 gram dan dikeringkan dalam oven pada suhu 100 - $105{ }^{\circ} \mathrm{C}$ selama \pm 15 menit untuk menghilangkan kadar air dalam sampel mikroalga Chlorella sp., kemudian sampel disimpan dalam desikator selama \pm 10 menit dan ditimbang. Sampel tersebut dipanaskan kembali dalam oven \pm 15 menit, disimpan dalam desikator dan ditimbang kembali. Perlakuan ini diulangi sampai berat konstan. Kadar air dalam mikroalga Chlorella sp. dihitung menggunakan persamaan (AOAC, 1984):

$$
\% \text { Kadar air }: \frac{b-c}{b-a} \times 100 \%
$$

Ket: $\quad \mathrm{a}=$ berat konstan cawan kosong

$\mathrm{b}=$ berat cawan + sampel sebelum

dikerigkan

$\mathrm{c}=$ berat konstan cawan + sampel setelah dikeringkan

\section{Ekstraksi Minyak Chlorella sp.}

28,33 g biomassa kering Chlorella sp. diekstraksi Soxhlet dengan n-heksana $227 \mathrm{~mL}$. Proses Soxhletasi dilakukan selama $6-8$ jam dengan suhu $80{ }^{\circ} \mathrm{C}$. Kemudian dilakukan pemekatan dengan menggunakan rotary evaporator, selanjutnya dilakukan pengeringan terhadap ekstrak pekat minyak mikroalga Chlorella sp. dengan aliran gas $\mathrm{N}_{2}$.

\section{Hidrolisis Minyak Chlorella sp.}

Sebanyak 1,38 g minyak dimasukkan ke dalam erlenmeyer 
kemudian ditambahkan dengan $5 \mathrm{~mL}$ metanol dan $\mathrm{KOH} 12 \%$. Direfluks pada suhu $60{ }^{\circ} \mathrm{C}$ selama 90 menit. Selanjutnya ditambahkan $15 \mathrm{~mL}$ aquades dan $15 \mathrm{~mL} \mathrm{n}$ heksana, dikocok dan didiamkan hingga terbentuk 2 lapisan (fase organik dan fase air). Fase air diambil dan ditambahkan dengan $\mathrm{H}_{2} \mathrm{SO}_{4} 1 \mathrm{M}$ hingga $\mathrm{pH}$-nya menjadi 1. Setelah itu ditambahkan n-heksana sebanyak $15 \mathrm{~mL}$, kemudian dilakukan pemisahan dengan menggunakan corong pisah. Fase organik yang diperoleh dipekatkan menggunakan rotary evaporator. Selanjutnya ekstrak pekat yang diperoleh dialiri gas $\mathrm{N}_{2}$.

\section{Uji Aktivitas Antibakteri}

\section{a) Sterilisasi Alat}

Sterilisasi alat dilakukan sebelum semua peralatan digunakan, yaitu dengan cara semua alat dibungkus menggunakan kertas dan disterilkan dalam autoklaf pada $121{ }^{\circ} \mathrm{C}$ dengan tekanan 15 psi (per square inci) selama 15 menit (Muhibah, 2013).

\section{b) Uji Aktivitas Antibakteri}

Media padat $10 \mathrm{~mL}$ yang telah dipanaskan hingga mencair, didinginkan sampai suhu $40{ }^{\circ} \mathrm{C}$, dan dituang dalam cawan petri steril. Ditambahkan $0,1 \mathrm{~mL}$ larutan biakan aktif bakteri $E$. coli dan $S$. aureus dihomogenkan. Dibiarkan hingga memadat. Kertas cakram (diameter $5 \mathrm{~mm}$ ) diresapkan dalam ekstrak Chlorella sp. dan kontrol. Proses peresapan dilakukan dengan cara meneteskan $20 \mu \mathrm{L}$ kontrol positif (penisilin dan streptomisin), kontrol negatif (pelarut) dan larutan ekstrak. Kertas cakram tersebut diletakkan di atas permukaan media bakteri menggunakan pinset dan ditekan sedikit. Media bakteri yang sudah diberi bahan antibakteri diinkubasi pada suhu $37{ }^{\circ} \mathrm{C}$ selama 24 jam dalam inkubator. Diameter zona hambatan yang terbentuk diukur menggunakan penggaris untuk menentukan aktivitas antibakteri (Volk dan Wheeler, 1993). Uji antibakteri dilakukan tiga kali pengulangan pada masing-masing konsentrasi. Luas zona hambat ditentukan dengan rumus:

$$
\text { Zona hambat }=\mathrm{a}-\mathrm{b}
$$

Dimana a merupakan diameter keseluruhan (zona hambat + zona hambat), b merupakan diameter cakram.

\section{Analisis Asam Lemak Chlorella sp. dengan KG-SM}

Analisis asam lemak Chlorella $s p$. menggunakan KG-SM QP2010S SHIMADZU. Sampel asam lemak yang telah diesterifikasi yaitu asam lemak hasil hidrolisis. Metil ester Chlorella sp. yang telah pekat tersebut diambil sebanyak $1 \mu \mathrm{L}$ kemudian diinjeksikan dalam instrument KG-SM yang telah dikondisikan sebagai berikut: jenis kolom AGILENTJ\%W DB-1 panjang kolom 30 meter, ID 0,25 mm, gas pembawa helium, sistem ionisasi Electron impact (EI), energi ionisasi $70 \mathrm{ev}$, suhu kolom $50{ }^{\circ} \mathrm{C}$, suhu injector $300{ }^{\circ} \mathrm{C}$, injection mode split, tekanan gas pembawa $12,0 \mathrm{kPa}$, kec. aliran gas $0,5 \mathrm{~mL} / \mathrm{menit}$, suhu detektor $250{ }^{\circ} \mathrm{C}$.

Hasil rekorder berupa kromatogram $\mathrm{KG}$ digunakan untuk menentukan analit komponen utama asam lemak Chlorella sp..

\section{HASIL DAN PEMBAHASAN}

\section{Kultivasi Chlorella sp. dalam Medium Ekstrak Tauge}

Selama kultivasi berlangsung warna kultur dalam labu berubah secara berangsur-angsur dari hijau muda menjadi semakin tua disertai terbentuknya endapan hijau. Hal tersebut mengindikasikan bahwa Chlorella sp. mengalami pertumbuhan dan kepadatan populasi. Pertumbuhan Chlorella sp. dimulai pada hari ke-0 sampai hari ke-10. Warna hijau yang dihasilkan disebabkan adanya pigmen klorofil yang dikandung Chlorella $s p$.

Pemenuhan nutrisi Chlorella $s p$. selama kultivasi diperoleh dari Medium Ekstrak Tauge (MET) $4 \%$ yaitu dengan 
menginokulasikan sebanyak $10 \mathrm{~mL}$ isolat ke dalam $60 \mathrm{~mL}$ medium ekstrak tauge 4 $\%$. Di dalam MET terkandung unsur-unsur makronutrien dan mikronutrien yang dibutuhkan selama proses fotosintesis.

\section{Pemanenan Chlorella sp.}

Pada penelitian ini, pemanenan Chlorella sp. dilakukan pada hari ke-8. Hal tersebut didasarkan pada penelitian Khamidah (2013) yang menyebutkan bahwa Chlorella sp. yang dikultivasi dalam MET $4 \%$ mengalami fase eksponensial dimulai pada hari ke-0 sampai hari ke-8. Namun, kelimpahan sel Chlorella sp. dalam MET $4 \%$ mengalami peningkatan secara signifikan ketika memasuki hari ke-8. Hal tersebut mengindikasikan bahwa kandungan lemak tertinggi dalam Chlorella sp. terjadi pada hari ke-8 atau fase akhir eksponensial. Tabel 1 memperlihatkan jumlah sel Chlorella sp. ketika berumur 7, 8, dan 9 hari.

Tabel 1 Jumlah sel Chlorella $s p$. hari ke 7, 8, dan 9

\begin{tabular}{cc}
\hline Hari & Jumlah Sel $(\mathrm{sel} / \mathrm{mL})$ \\
\hline Hari ke 7 & 42.720 .000 \\
Hari ke 8 & 48.160 .000 \\
Hari ke 9 & 48.640 .000 \\
\hline
\end{tabular}

Sobari, dkk. (2013) dalam penelitiannya juga menyebutkan bahwa kandungan lemak mikroalga yang mencapai puncak tertinggi terjadi pada fase eksponensial. Karbohidrat berlebih yang dihasilkan mikroalga saat proses fotosintesis akan disimpan dalam bentuk lipid. Dalam penelitiannya juga menunjukkan bahwa berat lipid rata-rata semakin meningkat seiring dengan massa pertumbuhan.

Bimassa Chlorella sp. yang diperoleh saat pemanenan berupa pasta berwarna hijau pekat yang masih mengandung air. Berat basah mikroalga Chlorella sp. yang diperoleh yaitu sebesar $1.452 \mathrm{~g}$.

\section{Preparasi Sampel}

Preparasi sampel dilakukan dengan pengeringan biomassa Chlorella sp. menggunakan oven pada suhu $30{ }^{\circ} \mathrm{C}$ selama 24 jam. Hasil rendemen pengeringan biomassa basah Chlorella $s p$. adalah $2,069 \%$. Artinya, dari $\pm 1.452,0095$ $\mathrm{g}$ biomassa basah, setelah dikeringkan diperoleh $\pm 30 \mathrm{~g}$ biomassa kering yang telah berbentuk serbuk halus.

\section{Analisa Kadar Air Chlorella sp.}

Sampel yang digunakan untuk analisis kadar air adalah Chlorella sp. yang sudah berupa serbuk kering. Penentuan kadar air ini dilakukan dengan proses pemanasan terhadap sampel dalam oven pada suhu $100-105^{\circ} \mathrm{C}$. Pada penelitian ini, kadar air yang diperoleh adalah sebesar $8,89 \%$.

\section{Ekstraksi Chlorella sp.}

Kelebihan mengekstrak minyak dari mikroalga Chlorella sp. dibandingkan dengan bahan alam lainnya adalah serbuk keringnya dapat langsung diekstrak dengan pelarut nonpolar tanpa perlu proses penggilingan.

Ekstraksi minyak Chlorella $s p$. dilakukan dengan mengekstrak serbuk Chlorella sp. sebanyak 28,33 g dengan pelarut n-heksana sebanyak $227 \mathrm{~mL}$ (1:8). Dalam penelitian ini, minyak telah terekstrak secara maksimal terjadi selama 855 menit dimana setiap satu sirkulasi berlangsung selama kurang lebih 20 menit. Pemilihan metode Soxhletasi untuk mengekstrak minyak dalam Chlorella $s p$. didasari oleh sifat dari minyak yang tahan terhadap proses pemanasan.

Hasil penelitian menunjukkan bahwa ekstraksi minyak Chlorella $s p$. umur panen hari ke-8 menggunakan ekstraktor Soxhlet dengan pelarut nheksana diperoleh rendemen sebesar 6,28 $\%$. Artinya, dari 28,33 g sampel serbuk Chlorella sp. diperoleh minyak Chlorella sp. $1,78 \mathrm{~g}$. 
Minyak yang diperoleh berwarna kuning kecoklatan. Warna yang dihasilkan diduga berasal dari pigmen karotenoid yang terkandung di dalam Chlorella sp.. Menurut Volesky (1970) selain mengandung klorofil $\mathrm{a}$ dan $\mathrm{b}$ dalam jumlah yang besar, Chlorella sp. juga mengandung karotin dan xantofil. Karotenoid merupakan kelompok pigmen yang berwarna kuning, jingga, merah jingga serta larut dalam minyak (Winarno, 2004). Menurut Ranganna (1979) karotenoid termasuk senyawa lipida yang tidak tersabunkan, larut dengan baik dalam pelarut organik tetapi tidak larut dalam air.

\section{Hidrolisis Minyak Chlorella sp.}

Asam lemak dapat dipisahkan dari gliserolnya melalui reaksi hidrolisis. Dalam penelitian ini sebanyak $1,38 \mathrm{~g}$ minyak Chlorella $s p$. dihidrolisis dengan katalis basa $\mathrm{KOH} 12 \%$ dalam $5 \mathrm{~mL}$ pelarut metanol. Beberapa keuntungan apabila menggunakan katalis basa adalah reaksi berjalan secara irreversible sehingga produk yang dihasilkan lebih banyak. Dalam hal ini KOH yang digunakan dibuat berlebih supaya proses penyabunan berjalan secara sempurna atau disebutkan juga dengan hidrolisis total. Darmoyuwono (2006) menerangkan bahwa apabila jumlah $\mathrm{KOH}$ yang digunakan lebih sedikit dari jumlah minyak yang akan dihidrolisis maka tidak semua minyak akan tersabunkan atau disebut juga hidrolisis parsial.

Warna ekstrak yang diperoleh adalah coklat kekuningan kental berupa campuran-campuran asam lemak dan senyawa lain dengan rendemen hidrolisis sebesar $69,57 \%$.

\section{Uji Aktivitas Antibakteri Asam Lemak Chlorella sp.}

Pengujian aktivitas antibakteri asam lemak Chlorella sp. dilakukan secara in vitro terhadap dua jenis bakteri uji yaitu bakteri $E$. coli yang mewakili bakteri gram negatif dan $S$. aureus yang mewakili bakteri gram positif. Hasil uji aktivitas antibakteri asam lemak Chlorella $s p$. dengan variasi konsentrasi dapat dilihat dalam Tabel 2.

Tabel 2.Hasil uji aktivitas antibakteri asam lemak Chlorella sp.

\begin{tabular}{ccc}
\hline \multirow{2}{*}{ Konsentrasi $(\% \mathrm{~b} / \mathrm{v})$} & \multicolumn{2}{c}{ Zona Hambat $(\mathrm{mm})$} \\
\cline { 2 - 3 } & E. coli & S. aureus \\
\hline 0,5 & - & 1,8 \\
1,0 & - & 1.9 \\
1,5 & - & 3,2 \\
2,0 & - & 3,5 \\
2,5 & - & 3 \\
Kontrol n-Heksana & - & - \\
Kontrol Media & - & - \\
Penisilin 0,6 & & 24 \\
Streptomisin 2,5 & 12 & \\
\hline
\end{tabular}

Berdasarkan Tabel 2 dapat dikatakan bahwa asam Chlorella sp. pada konsentrasi $\quad 0,5 \quad-\quad 2,5 \%$ sudah menunjukkan adanya aktivitas antibakteri terhadap bakteri $S$. aureus walaupun tergolong lemah, namun tidak menunjukkan adanya aktivitas antibakteri terhadap bakteri E. coli.

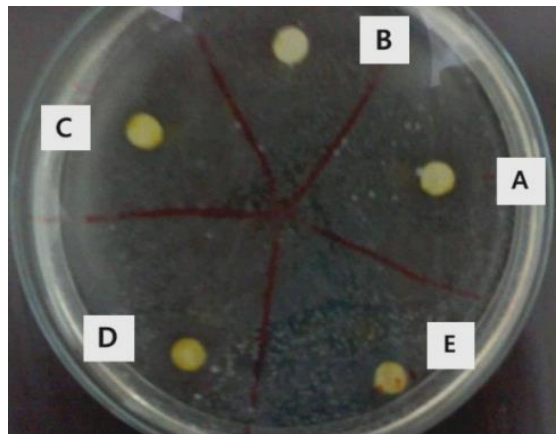

Gambar 1. Zona hambat pada bakteri S. Aureus Keterangan: A. konsentrasi 0,5\%, B. konsentrasi 1 $\%$, C. konsentrasi $1,5 \%$, D. konsentrasi 2,5\%, E. konsentrasi 2,5\%.

\section{Analisis Asam Lemak Chlorella sp. dengan KG-SM}

Berdasarkan hasil analisis KG-SM dapat diketahui komposisi asam lemak dominan yang terkandung dalam Chlorella sp. adalah asam 9,12-oktadekadienoat (asam linoleat), asam heksadekanoat (asam palmitat), asam dodekanoat (asam laurat), 
asam 7,10-heksadekadienoat, dan asam 10,13-oktadakadienoat. Tabel 3 menunjukkan kromatogram $\mathrm{KG}$ metil ester asam lemak hasil hidrolisis.

Tabel 3 Asam-asam lemak dominan pada Chlorella sp.

\begin{tabular}{ccclc} 
No. & Puncak & $\begin{array}{c}\text { Waktu Retensi } \\
\text { (menit) }\end{array}$ & \multicolumn{1}{c}{ Asam Lemak } & $\begin{array}{c}\text { \% Area } \\
\text { Relatif }\end{array}$ \\
\hline 1. & 3 & 27,185 & $\begin{array}{l}\text { asam dodekanoat } \\
\text { (asam laurat) }\end{array}$ & 7,43 \\
\hline 2. & 11 & 35,685 & asam 7,10-heksadekadienoat & 6,20 \\
3. & 14 & 36,398 & $\begin{array}{l}\text { asam heksadekanoat } \\
\text { (asam palmitat) }\end{array}$ & 12,74 \\
4. & 17 & 37,908 & asam 10,13-oktadakadienoat & 5,72 \\
5. & 21 & 39,848 & asam 9,12-oktadekadienoat (asam linoleat) & 19,95 \\
\hline
\end{tabular}

Asam 9,12-oktadekadienoat (asam linoleat), asam heksanoat (asam palmitat), dan asam dodekanoat (asam laurat) hasil hidrolisis minyak Chlorella sp. merupakan senyawa yang aktif menghambat bakteri $S$. aureus. Hal tersebut sesuai dengan penelitian Agustini dan Kusmiati (2010) yang menyebutkan bahwa asam 9,12oktadekadienoat (asam linoleat) merupakan senyawa yang bersifat sebagai antibakteri. Hasil penelitian lain yang dilakukan oleh Kusmiyati (2007) menghasilkan kesimpulan bahwa hasil identifikasi senyawa antibakteri dari mikroalga Porphyridium cruentum dengan KG-SM menunjukkan senyawa dominan yaitu asam lemak metil heksadekanoat (asam palmitat). Sementara itu, menurut Murhadi (2009) asam lemak seperti miristoleat, palmitoleat, linolenat, kaprat, laurat, dan miristat juga terbukti memiliki aktivitas antibakteri terhadap bakteri $S$. aureus.

\section{PENUTUP \\ Kesimpulan}

Asam lemak hasil hidrolisis minyak mikroalga Chlorella sp. memiliki aktivitas antibakteri terhadap bakteri $S$. aureus, tetapi tidak terhadap bakteri $E$. coli. Zona hambat asam lemak Chlorella sp. terhadap bakteri $S$. aureus pada konsentrasi 0,$5 ; 1$; 1,$5 ; 2$; dan $2,5 \%$ secara berturut-turut adalah 1,$8 ; 1,9 ; 3,2 ; 3,5$; dan $3 \mathrm{~mm}$.

\section{Saran}

1. Perlu dilakukan pemisahan asam lemak jenuh dan tak jenuh Chlorella sp. agar diperoleh keefektifan antibakteri yang lebih besar.

2. Perlu dilakukan pengujian asam lemak sebagai antibakteri terhadap beberapa jenis bakteri gram positif lainnya.

\section{DAFTAR PUSTAKA}

Agustini, N. W. S. dan Kusmiati. 2010. Identifikasi dan Uji Aktivitas Antibakteri Senyawa Aktif Secara Maserasi dan Digesti dalam Berbagai Pelarut dari Mikroalga Dulaniella salina. Seminar Nasional IX Pendidikan Biologi FKIP UNS: 544-551.

AOAC. 1984. Official Methods of Analysis of the Association of Official Analytical Chemists. Washington DC: Association of Official Analytical Chemists.

Chisti, Y. 2007. Biodiesel from Microalgae. Biomass, 25, pp. 294306.

Damianus, M. 2011. Aktivitas Ekstrak Mikroalga sebagai Inhibitor Helikase Virus Japanese Enchephalitis. Skripsi Tidak Diterbitkan. Bogor: Institut Pertanian Bogor.

Darmoyuwono, W. 2006. Gaya Hidup Sehat dengan Virgin Coconut Oil. Jakarta: Gramedia. 
Fasya, A.Ghanaim. 2011. Sintesis Metil 10, 12, 14-oktadekatrienooat Dari (Asam $\alpha$-linoleat) Biji Selasih (Ocimum basilicum) dan Uji Bioaktifitasnya. Thesis: Universitas Brawijaya: Malang.

Kellam, S. dan Walker, J. 1989. Antibacterial Activity from Marine Microalgae in Laboratory Culture. Br. Phycol. J. Volume 24: 191-194.

Khamidah, U. 2013. Uji Aktivitas Antibakteri Ekstrak Metanol Mikroalga Chlorella sp. Hasil Kultivasi dalam Medium Ekstrak Tauge terhadap Eschericia coli dan Staphylococcus aureus. Skripsi Tidak Diterbitkan. Malang: UIN Maulana Malik Ibrahim Malang.

Kusmiyati; Ni Wayan S. A. 2007. Uji Aktivitas Senyawa Antibakteri dari Mikroalga Porphyridium cruentum. Biodiversitas. Volume 8, Nomor 1: 48-53.

Merizawati. 2008. Analisis Sinar Merah, Hijau dan Biru (RGB) untuk Mengukur Kelimpahan Fitoplankton (Chlorella sp.). Skripsi Diterbitkan. Bogor: Fakultas Perikanan dan Ilmu Kelautan IPB.

Muhibah, S. R. N. 2013. Uji Golongan Senyawa Aktif dan Uji Aktivitas Antibakteri Ekstrak Alga Merah Eucheuma Cottonii dari Petani Lobuk Madura. Skripsi Tidak Diterbitkan. Malang: Jurusan Kimia Universitas Islam Negeri (UIN) Maulana Malik Ibrahim Malang.

Murhadi. 2009. Senyawa dan Aktivitas Antimikroba Golongan Asam Lemak dan Esternya dari Tanaman. Jurnal Teknologi Industri dan Hasil Pertanian. Volume 14, No. 1: 97-105.
Nuriyani.

2011.

http://nationalgeographic.co.id/for um/topic.php?id= 1135. (Diakses pada tanggal 15 September 2013).

Prihantini, N.H, Putri B., dan Yuliati R. 2005. Pertumbuhan Chlorella sp. dalam Medium Ekstrak Tauge (MET) dengan Variasi $\mathrm{pH}$ Awal. Makara, Sains, IX (1): 1-6.

Putri, A.L. 2013. Waspada Bakteri E. Coli pada Kolam Renang. http: // www. tempo .co /read/news/2013/05/18/06148129 5/Waspada-Bakteri-E-Coli-padaKolam-Renang/1/1. (Diakses pada tanggal 15 September 2013).

Rachmaniah, O.; Setyarini R. D.; Maulida, L. 2010. Pemilihan Metode Ekstraksi Minyak Alga dari Chlorella sp. dan Prediksinya sebagai Biodiesel. Seminar Teknik Kimia Soehadi Reksowardojo.

Ranganna, S. 1979. Manual of Analysis of Fruit and Vegetable Products. New York: Tata Mc. Graw Hill Publ. Co., Limited.

Ryan, K.J., J.J. Champoux, S. Falkow, J.J. Plonde, W.L. Drew, F.C. Neidhardt, and C.G. Roy. 1994.

Saadudin, E.; Fitri, S. dan Wargadalam, V. 2011. Karakteristik Asam Lemak Mikroalga untuk Produksi Biodiesel. Ketenagalistrikan dan Energi Terbarukan. Volume 10, Nomor 2: 131-140.

Sobari, R.; A.B. Susanto; Dwi, S.; Delicia, Y. 2013. Kandungan Lipid Beberapa Jenis Sianobakteria Laut Sebagai Bahan Sumber Penghasil Biodiesel. Journal of Marine Research. Volume 2, Nomor 1: $112-119$.

Steenblock. 1996. Chlorella Makanan Sehat Alami. Jakarta: Gramedia Pustaka Utama.

Volesky, G. 1970. Algal Product. New Delhi: In Properties of Algal (Ed) Penum Press. 
Volk. W.A dan M.F. Wheeler. 1993. Mikrobiologi Dasar, Alih Bahasa: Markham. Jakarta: PT. Glora Aksara Pratama.

Winarno; Fardias dan Fardias. 1973. Ekstraksi, Kromatografi dan Elektroforesis. Bogor: Institut Pertanian Bogor. 